\title{
SHALLOW DEPRESSIONS IN THE FLORIDA COASTAL PLAIN: KARST AND PSEUDOKARST
}

\author{
Sam B. Upchurch \\ SDII Global Corporation, 4509 George Road, Tampa, Florida 33634, USA, flwaterdoc@gmail.com, \\ Thomas M. Scott \\ SDII Global Corporation, 4509 George Road, Tampa, Florida 33634, USA, tscott@sdii-global.com
}

Michael C. Alfieri

WRA Engineering, 4260 West Linebaugh Avenue, Tampa, Florida 33624, USA, malfieri@wraengineering.com

Thomas L. Dobecki

SDII Global Corporation, 4509 George Road, Tampa, Florida 33634, USA, tdobecki@sdii-global.com

\begin{abstract}
In Florida, shallow depressions (i.e., depressions $<1-2$ $m$ in depth) on the land surface are often attributed to sinkhole development. However, it has become evident that there are at least seven different mechanisms through which these depressions can form in Florida's geologically young cover sediments. These mechanisms include:
\end{abstract}

1. Cover-subsidence sinkholes over shallow limestone;

2. Suffosion sinkholes over shallow limestone;

3. Cover settlement over shallow shell beds;

4. Large, aeolian deflation areas that resemble "Carolina bays";

5. Aeolian deflation depressions within dune trains;

6. Depressions that mimic landforms developed on a shallow paleosol; and

7. Depressions created by pedodiagenesis (i.e., conversion of smectite to kaolinite) in a soilforming environment.

Of these, only the first two appear to represent traditional mechanisms for sinkhole development in eogenetic karst. Cover settlement over shell beds is poorly understood and incorrectly attributed to sinkhole-development processes. Development of this type of depression is limited by cover thickness, textural, and shell content constraints. The last three mechanisms are pseudokarst features created by aeolian and soil-forming processes.
In this paper we present examples of each and discuss their constraints and evidence.

\section{Introduction}

As a result of Florida's statutory requirement for sinkhole insurance coverage, much emphasis has been placed on identification of locations where sinkholes are developing and causing property damage. One issue related to identification of existing sinkholes deals with the origins of shallow, nearly circular to amoeboid depressions in the land surface (Figure 1), which abound in Florida. These features vary from seasonal wetlands, shallow ponds, to indistinct, dry depressions.

One issue that is widely debated is whether or not these shallow depressions in the land surface represent coversubsidence sinkholes (White, 1988; Beck and Sinclair, 1986) [a.k.a. solution dolines, Field, 2002].

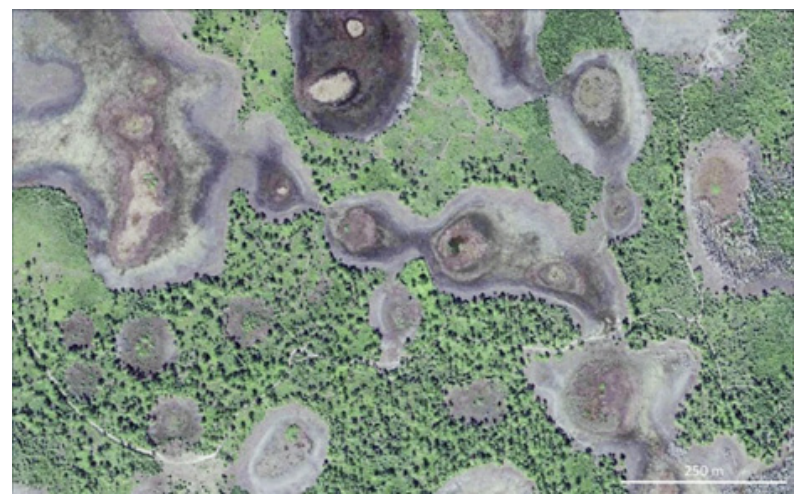

Figure 1. Closed depressions in the Big Cypress Swamp in Collier County, southwestern Florida. Depressions are seasonal wetlands. 
Over the last few decades, the authors have conducted over 10,000 sinkhole investigations using surface geophysics, standard penetration testing (SPT), and cone penetrometer test (CPT) methods, studied cross sections of depressions exposed in quarries and borrow pits, and mapped these depressions. This paper presents our observations as to the origins of these depressions. Complete descriptions and data will be presented in a textbook, which is being written by the authors.

\section{Overview}

Based on our observations, it is apparent that closed depressions in Florida have a number of possible origins, some of which are karst-related while others can be considered pseudokarst (Field, 2002; Halladay, 2007). We have identified at least seven different mechanisms for formation of these depressions (Table 1), including

1. Cover-subsidence sinkholes over shallow limestone;

2. Suffosion sinkholes over shallow limestone;

3. Cover settlement over shallow shell beds;

4. Large, aeolian deflation areas that resemble "Carolina bays";

5. Aeolian deflation depressions within dune trains;

6. Depressions that mimic landforms developed on a covered, shallow paleosol; and

7. Depressions created by pedodiagenesis (i.e., conversion of smectite to kaolinite) in a soilforming environment.

Visual identification of the depression is insufficient to determine its cause. Only subsurface testing combined with petrographic examination of the carbonate fractions in the sediment can truly determine if the depression was caused by dissolution of limestone or shell material.

Furthermore, use of estimates of the rate of development of the depression are insufficient to determine if the cause of the depression is cover subsidence, a process wherein the rate of subsidence is governed by the rate of carbonate dissolution, which takes thousands to hundreds of thousands of years to create volume loss sufficient to cause a depression. Cover-collapse sinkholes are also common in Florida, and the rate of cover collapse can be sudden, occurring in minutes to hours, or slow if the void into which the cover collapses has limited volume or the collapsed materials undergo long-term consolidation.

\section{Mechanisms of Depression Formation}

The following sections present the authors' opinions as to origins and examples of each of these depressionforming mechanisms.

\section{Cover-Subsidence Sinkholes}

True, cover-subsidence sinkholes (Table 1) are common in those areas of Florida where limestone is within a few meters of the land surface. They form as the upper surface of the limestone is dissolved away and the cover materials (sand- and clay-rich sediments) slowly subside to replace the volume lost to dissolution. The dissolution surface is often in the vadose zone, but evidence of cover-subsidence in shallow phreatic environments has been observed. Simple SPT boring observations do not allow for determination as to whether the phreatic dissolution surfaces are currently undergoing dissolution or not. A geochemical investigation is required to make this determination.

Even if dissolution is currently underway, the rate of subsidence is governed by the rate of dissolution of the carbonate rock, not by collapse mechanisms. This is of special interest in many areas of Florida where the limestone is overlain by Mio-Pliocene clayey sediments and/or Quaternary marine sand deposits. If the limestone is in contact with clay, dissolution may be limited because of permeability and groundwater flow-path limitations.

In addition to the relative depth of the water table and lithology of the cover material, there appears to be a cover thickness issue that limits the depth to which dissolution of the upper limestone surface can create a land-surface depression. In Florida's predominantly sandy cover materials, small amounts of limestone dissolution and concomitant settlement of the sand causes dilatation and a slight increase in porosity of the sand cover. This loss of packing density and increase in porosity must be of sufficient magnitude to translate to the land surface and cause a depression to develop.

It is important to understand the difference between cover subsidence and cover collapse. This paper deals only with cover subsidence sinkholes, which form at the rate of dissolution of the underlying carbonate stratum and where the cover materials are sandy marine strata, 
Table 1. Summary of the types and properties of surficial depressions observed on the Florida coastal plain.

\begin{tabular}{|c|c|c|c|c|}
\hline Depression Type & $\begin{array}{l}\text { Mode of Depression } \\
\text { Development }\end{array}$ & Rate of Development & Probable Evidence & $\begin{array}{l}\text { Predominant Scale and } \\
\text { Shape }\end{array}$ \\
\hline \multirow{2}{*}{$\begin{array}{l}\text { Cover-subsidence } \\
\text { sinkhole [solution } \\
\text { doline] }\end{array}$} & \multirow{2}{*}{$\begin{array}{l}\text { Soil/sediment subsidence } \\
\text { as result of dissolution of } \\
\text { limestone surface }\end{array}$} & \multirow[t]{2}{*}{$\begin{array}{l}\text { Slow (thousands to hundreds } \\
\text { of thousands of years) }\end{array}$} & $\begin{array}{l}\text { 1. Limestone fragments that } \\
\text { show evidence of dissolution }\end{array}$ & \multirow{2}{*}{$\begin{array}{l}<100 \mathrm{~m} \text { in diameter; } \\
\text { relatively circular unless } \\
\text { they intersect each other }\end{array}$} \\
\hline & & & $\begin{array}{l}\text { 2. Leached sand and/ } \\
\text { or organics in depression } \\
\text { sediments }\end{array}$ & \\
\hline \multirow[t]{2}{*}{ Suffosion sinkhole } & \multirow{2}{*}{$\begin{array}{l}\text { Raveling of non-cohesive } \\
\text { sediment into pre-existing } \\
\text { void space in limestone }\end{array}$} & \multirow{2}{*}{$\begin{array}{l}\text { Varies, may be rapid or } \\
\text { moderately slow (decades } \\
\text { to centuries) if void space } \\
\text { volume limits ability of } \\
\text { cover materials to ravel }\end{array}$} & $\begin{array}{l}\text { 1. Non-cohesive sediment } \\
\text { directly overlies limestone }\end{array}$ & \multirow[t]{2}{*}{$\begin{array}{l}<10 \mathrm{~m} \text { in diameter; more or } \\
\text { less circular }\end{array}$} \\
\hline & & & $\begin{array}{l}\text { 2. Disruption of sediment } \\
\text { structure in void fill and } \\
\text { slopes of depression }\end{array}$ & \\
\hline \multirow[t]{2}{*}{$\begin{array}{l}\text { Cover settlement over } \\
\text { shell beds }\end{array}$} & 1. Dissolution of shell & \multirow[t]{2}{*}{$\begin{array}{l}\text { Slow (thousands to hundreds } \\
\text { of thousands of years) }\end{array}$} & $\begin{array}{l}\text { 1. Shell fragments that show } \\
\text { evidence of dissolution }\end{array}$ & \multirow{2}{*}{$\begin{array}{l}<100 \mathrm{~m} \text { in diameter; more } \\
\text { or less circular unless they } \\
\text { intersect each other }\end{array}$} \\
\hline & $\begin{array}{l}\text { 2. Minor consolidation and } \\
\text { sediment migration into } \\
\text { primary porosity }\end{array}$ & & $\begin{array}{l}\text { 2. Crushing of shells and } \\
\text { traces of collapsed and } \\
\text { dissolved shell }\end{array}$ & \\
\hline \multirow[t]{3}{*}{ "Carolina bays" } & $\begin{array}{l}\text { 1. Lowering of water } \\
\text { table, possibly as a result } \\
\text { of sinkhole development, } \\
\text { allows for fine sand to be } \\
\text { eroded by wind stress. }\end{array}$ & \multirow[t]{3}{*}{$\begin{array}{l}\text { Apparently not forming } \\
\text { today; assumed to be } \\
\text { formed on the scale of } \\
\text { decades }\end{array}$} & $\begin{array}{l}\text { 1. Lake, pond, or wetland } \\
\text { depression within larger } \\
\text { depression at point of } \\
\text { maximum deflation }\end{array}$ & \multirow{3}{*}{$\begin{array}{l}\text { Long axis of large } \\
\text { depression is up to } 1,000 \\
\text { m. Smaller sinkhole-like } \\
\text { depressions within the } \\
\text { deflation zone are typically } \\
\text { more or less circular and } \\
\text { up to } 100 \mathrm{~m} \text { in diameter. } \\
\text { Depressions are ovoid with } \\
\text { long axis oriented northeast } \\
\text { to southwest, the apparent } \\
\text { prevailing wind direction; }\end{array}$} \\
\hline & $\begin{array}{l}\text { 2. Low basin forms at } \\
\text { upwind end of depression } \\
\text { and a parabolic dune } \\
\text { train accumulates at the } \\
\text { downwind end of the } \\
\text { depression. }\end{array}$ & & $\begin{array}{l}\text { 2. In Florida, the deepest } \\
\text { area within the larger } \\
\text { depression is located on } \\
\text { the southwest end of the } \\
\text { northeast to southwest } \\
\text { oriented feature }\end{array}$ & \\
\hline & $\begin{array}{l}\text { 3. Deflation within the } \\
\text { "bay" reveals depressions } \\
\text { and possible relict sinkholes } \\
\text { in the bottom of the larger, } \\
\text { deflation-derived depression }\end{array}$ & & $\begin{array}{l}\text { 3. Parabolic dunes developed } \\
\text { on upwind, northeastern } \\
\text { quarter of the larger } \\
\text { depression }\end{array}$ & \\
\hline $\begin{array}{l}\text { Aeolian deflation } \\
\text { depressions }\end{array}$ & $\begin{array}{l}\text { Erosion by wind stresses } \\
\text { within dune trains }\end{array}$ & $\begin{array}{l}\text { May be rapid depending on } \\
\text { wind stresses and vegetation } \\
\text { cover }\end{array}$ & $\begin{array}{l}\text { No subsurface expression; } \\
\text { deflation zones typically } \\
\text { parallel dune long axes }\end{array}$ & $\begin{array}{l}\text { Depressions are complex } \\
\text { and may be elongated, } \\
\text { oriented parallel to the long } \\
\text { axes of the dune train; the } \\
\text { long axes of the depressions } \\
\text { are typically less than } 100 \mathrm{~m}\end{array}$ \\
\hline \multirow[t]{2}{*}{$\begin{array}{l}\text { Depressions over } \\
\text { paleosol and epikarst } \\
\text { features }\end{array}$} & $\begin{array}{l}\text { 1. Fine-grained, marine } \\
\text { terrace sand deposited } \\
\text { over, and infilling, existing } \\
\text { depressions developed on } \\
\text { the late Miocene to early } \\
\text { Pliocene paleosol }\end{array}$ & \multirow[t]{2}{*}{$\begin{array}{l}\text { Slow (hundreds to thousands } \\
\text { of years) }\end{array}$} & $\begin{array}{l}\text { 1. Depression floored by } \\
\text { paleosol with no evidence of } \\
\text { deeper limestone dissolution }\end{array}$ & \multirow[t]{2}{*}{$\begin{array}{l}\text { Scale varies with circular } \\
\text { depressions up to } 200 \mathrm{~m} \text { and } \\
\text { streams kilometers in length. } \\
\text { Depressions are circular } \\
\text { to linear; infilled stream } \\
\text { systems are often occupied } \\
\text { by modern streams; }\end{array}$} \\
\hline & $\begin{array}{l}\text { 2. Consolidation and minor, } \\
\text { early compaction of the } \\
\text { relatively thicker sand within } \\
\text { the infilled depressions } \\
\text { causes development of } \\
\text { depressions in the land } \\
\text { surface }\end{array}$ & & $\begin{array}{l}\text { 2. Infilling sediments down } \\
\text { warped by compaction; } \\
\text { wetland or stream sediments } \\
\text { may be included within fill } \\
\text { materials }\end{array}$ & \\
\hline Pedogenetic depressions & $\begin{array}{l}\text { Late Miocene to early } \\
\text { Pliocene alteration of } \\
\text { Miocene smectite to } \\
\text { kaolinite, a pedogenetic } \\
\text { process, causes volume } \\
\text { reduction and land-surface } \\
\text { depressions }\end{array}$ & $\begin{array}{l}\text { Very slow (thousands to } \\
\text { millions of years) }\end{array}$ & $\begin{array}{l}\text { Clay flooring and bordering } \\
\text { depression is kaolinite rich } \\
\text { as compared to more distant, } \\
\text { smectite-rich sediments }\end{array}$ & $\begin{array}{l}\text { Scale unknown; presumed to } \\
\text { be more or less circular }\end{array}$ \\
\hline
\end{tabular}


not weathering residue. Cover-subsidence sinkholes, therefore, develop over time frames of hundreds to thousands of years.

Cover collapse occurs as a result of failure of sediments that bridge voids. The collapse may be a result of piping failure or loss of resistance to bridging forces over a void. As a result, cover-collapse sinkholes in the Florida coastal plain develop rapidly (hours to years) in cover sediments that exhibit sufficient cohesion or structural strength to bridge a void. Because of their mode of development, cover-collapse sinkholes can be quite deep.

\section{Suffosion Sinkholes}

Suffosion or simple raveling without concomitant collapse of non-cohesive sediments into pre-existing void space can also cause small-scale depressions. These are common where the limestone is geologically young, near the land surface, and covered with sand, not insoluble residues created by limestone dissolution. The most notable locations are in the Miami and Big Cypress Swamp areas of southern Florida where limestone is within a meter of the land surface and the cover is non-cohesive sand. Figure 2 illustrates solution holes in the caprock of southern Florida. These solution holes and pipes are commonly sites where sand migrates downward creating small, suffosion-related depressions.

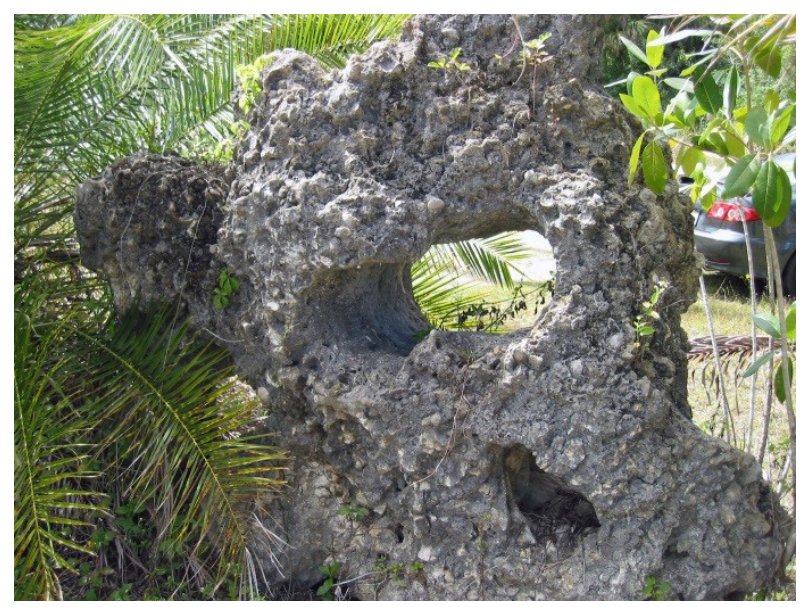

Figure 2. Caprock, a sandy limestone formed by repeated wetting and drying of shelly sand, penetrated by solution channels through which suffosion of sand occurs. Rock has been turned vertically on edge to serve as "yard art."

\section{Depressions Caused by Cover Settlement over Shell Beds}

Whether or not depressions caused by cover settlement over shell beds represent cover-subsidence sinkholes is problematic. These depressions are common on land surfaces underlain by late Neogene and Quaternary sand and shell strata. Where they exist and appear to be related to dissolution of shell material, the shell material is observed to be at a minimum of 50 percent of the sediment volume, and within a few meters of the land surface. Observations of hundreds of these features in SPT borings and borrow pits indicate that sediments with less than at least 50 percent shell material (Figure 3A) and deeper than about $3 \mathrm{~m}$ do not cause depressions or subsidence at the land surface because of lack of shell dissolution and the volume constraints mentioned under cover-subsidence sinkholes above.

White (1970) discussed the origins of these features in southern Florida and attributed them to both dissolution of carbonate sediments and differential settlement after oxidation and/or compression of organic sediments. He referred to these depressions as sag features. Schmidt and Scott (1984) referred to them as "karst depressions."

Recognition of shallow subsidence features developed by dissolution of shallow shell beds requires petrographic examination of the shells immediately under these depressions in order to determine if the shells and/or shell fragments have undergone substantial dissolution. Note that a very large proportion of the shell $(>>50 \%)$ must be removed in order to create sufficient volume reduction for a depression to form. Evidence of dissolution includes rounding of sharp corners, erosion of shell decorations, development of shiny surfaces as if the shells were dipped in acid, and/or development of "punky", earthy surfaces as aragonitic components are selectively removed from the shell by dissolution. In many examples, the shell has been completely removed and only the "ghosts" of collapsed shells and/or molds of shells remain (Figure 3B).

Siliciclastic sediments in soil zones where the shell has been weathered and subjected to dissolution often contain abundant ferric hydroxide, which gives the sediment/soil a reddish hue, organics, and crude Liesegang banding is often present. 


\section{Depressions That Resemble "Carolina Bays"}

In west-central Florida there are at least ten large, shallow depressions that resemble "Carolina bays." Carolina bays are circular to oval wetland depressions that occur on the Atlantic Coastal Plain from New York to Florida. Swarms of the bays have a common orientation, which suggests a common origin, and they often have small, parabolic sand dunes at one end of the elliptical depressions (the presumed down-wind side; Figure 4). The common orientation and dunes suggest that wind, or some other unidirectional transport mechanism played a role in their formation.

The origin of the Carolina bays has been the subject of a long, and sometimes intense, debate. The origins of Carolina bays have been attributed to one, or a combination of, the following processes:

- Meteorite or comet impacts (Prouty, 1935, 1952; Wells and Boyce, 1953);
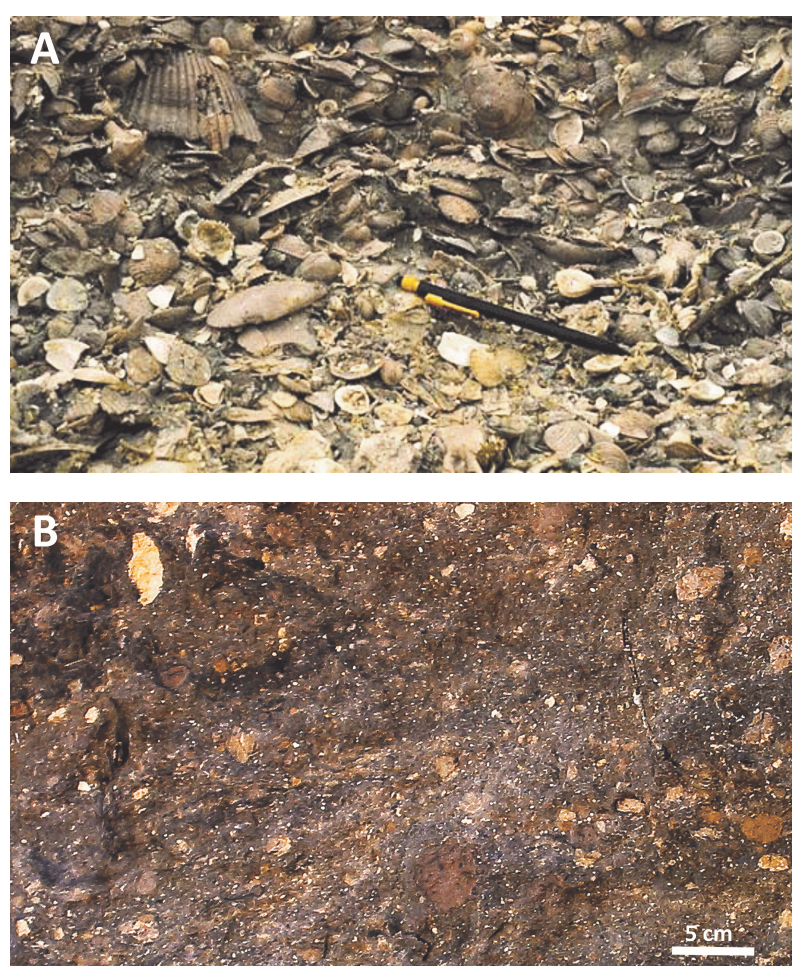

Figure 3. Examples of unweathered and undissolved shell material (A) and weathered shell material from a shallow depression (B). Note the angular and well-decorated shells in A and the rounded and highly dissolved shells in a stratum enriched in ferric hydroxide and organics in B, where collapsed shells and molds are common.

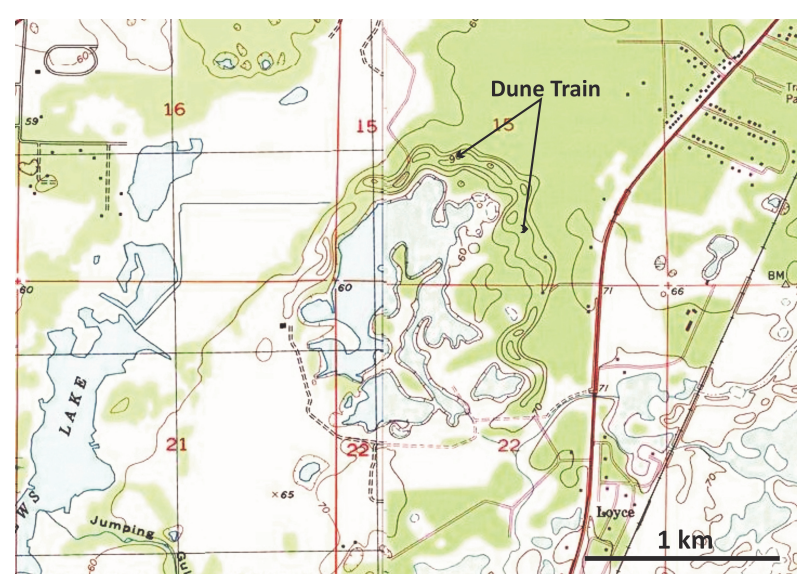

Figure 4. An example of a Carolina bay-like depression in west-central Florida. Note the parabolic dune train in the northeastern quadrant and the ephemeral lake/wetland in the center and southwestern quadrant.

- Substrate dissolution and sinkhole development (LeGrand, 1953; May and Warne, 2004; Willoughby, 2007);

- Deflation as a result of eolian erosion and transport (Grant et al., 1998; Ivester et al., 2007); and

- Marine sedimentation patterns (Cooke, 1954).

See also Eyton and Parkhurst (1975) for a summary of these diverse potential causes.

Carolina bays are thought to have formed sometime in the period from 10,000 to 100,000 years ago (Schalles et al., 1989; Brooks et al., 2001; Ivester et al., 2007).

There exist in Florida a number of circular depressions that bear some resemblance to Carolina bays. They are circular to elliptical in outline, occur in clusters, and the depressions show a common orientation from southwest to northeast. They have parabolic, aeolian dunes in the northeast quadrant, the apparent down-wind quadrant of the depressions. Most have small ephemeral lakes or wetlands near the center or southwest third of the depression. The interiors of the wetlands are dotted with what appear to be sinkholes, and SPT testing within the large depressions often presents evidence of sinkhole development and covered epikarst.

We hypothesize that these depressions were formed as a result of localized dewatering of sandy sediments, most likely as a result of sinkhole development during 
the Pleistocene. The dry, fine sand was then entrained by prevailing winds and accumulated in down-wind locations to form the parabolic dunes.

\section{Aeolian Deflation Depressions}

Florida has extensive, Pleistocene and Holocene aeolian dune fields. These are related to the modern coasts and ancient marine terraces. As is normal, these dunes are characterized by numerous inter-dune and dune-slope depressions. They have more or less circular to linear outlines and present on topographic maps and in the field as closed depressions, often with wetlands.

Because of the closed depressions on topographic maps, they have been mistaken for sinkholes, which are commonly interspersed with the deflation depressions. Only subsurface testing can differentiate them.

\section{Depressions over Paleosols}

One of the most remarkable features of west-central Florida's Polk-Desoto Plain Physiographic Province can only be appreciated from the air. As one flies over the area, the large number of circular, wetland depressions and streams with trellis drainage patterns becomes evident (Figure 5).

Observation of these depressions in cross section in phosphate mine cuts and in SPT borings indicates that many of these features are associated with the late Miocene/early Pliocene weathering surface,

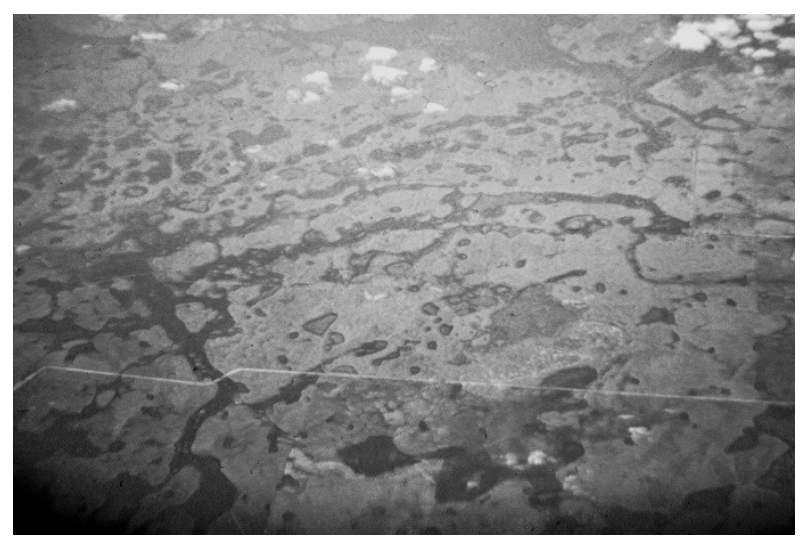

Figure 5. View of a portion of the Polk-DeSoto Plain Physiographic Province in Hardee County, central Florida. Many of the wetlands and streams are developed over somewhat thicker sands in pre-existing low areas developed on a late Miocene/early Pliocene paleosol. which resulted in a paleosol that is locally termed the "leached zone" (Altschuler et al., 1951; Van Kauwenbergh et al., 1990).

Pleistocene marine terrace sand is slightly thicker in depressions on the top of the paleosol, and during early sediment compaction the thickness of the sediments dictates the amount of change in thickness of the sediment overlying the paleosol. While the amount of compaction is minor and only changes the relative density of the sediments by small amount, the result is a depression. For example, if the sand body were $1 \mathrm{~m}$ in thickness when it was deposited and shortly after deposition it compacted under its own weight, groundwater percolation, and bioturbation by five percent, the resulting thickness would be $0.95 \mathrm{~m}$, which would likely not be visible. If, however, the sediment were $10 \mathrm{~m}$ in thickness when deposited, the post-settlement and compaction thickness would be $9.5 \mathrm{~m}$ and a $0.5 \mathrm{~m}$ depression would be visible. With a shallow water-table aquifer, this depression would likely be seasonally wet. This process has resulted in the patterns of drainage control and shallow depressions that are so common on the Polk-DeSoto Plain Province (Figure 5).

This process was identified on the Polk-DeSoto Plain by Cathcart (1963) who noted these features and stated that

"The subsurface topography of the Hawthorn is
similar to the present surface; ancestors of the
present surface streams flowed on the surface
of the Hawthorn at or close to their present
positions." (Cathcart 1963, p.1).

In other words, the drainage and depressions on the modern land surface mimic the buried topography of the late Miocene/early Pliocene land surface. Post depositional settlement is greatest where the PlioPleistocene sand mantle is thickest. With settlement, new drainage systems and wetlands occupy the resulting depressions. When the drainage ways are rectilinear or trellis-like (Figure 5), they were probably developed on weak fractures or other nearly orthogonal features developed in the more cohesive and carbonate-rich sediments of the underlying Miocene Hawthorn Group.

The most comprehensive investigation of these depressions was conducted at the future site of the C.W. "Bill" Young Regional Reservoir in southeastern Hillsborough County, Florida. Numerous circular 
wetlands and several small streams crossed the site (Figure 6). A geophysical and stratigraphic study was used to determine the origins and risks of these features to the reservoir (Upchurch et al., 1999; Dobecki and Upchurch, 2010). Every photolinear intersection, each depression, and the stream beds were tested by ground penetrating radar, seismic shear-wave analysis, and seismic reflection and refraction and then drilled using SPT techniques.

As shown in Figure 6, one problematic cover-collapse sinkhole resulted in moving the berm to avoid the risk. All of the other low areas were determined to reflect depressions in the underlying "leached zone" (the late Miocene/early Pliocene paleosol). Two of the depressions, indicated by the ERM boring designations on Figure 6, were found to be over ancient sinkhole depressions. One of the relict sinkholes was filled with Miocene smectitic clay and the other with well compacted Pliocene sand. Neither showed evidence of modern activity. The streams and all other wetland depressions were developed over depressions in the upper surface of the paleosol but had no subsurface expression in the underlying Miocene and older strata.

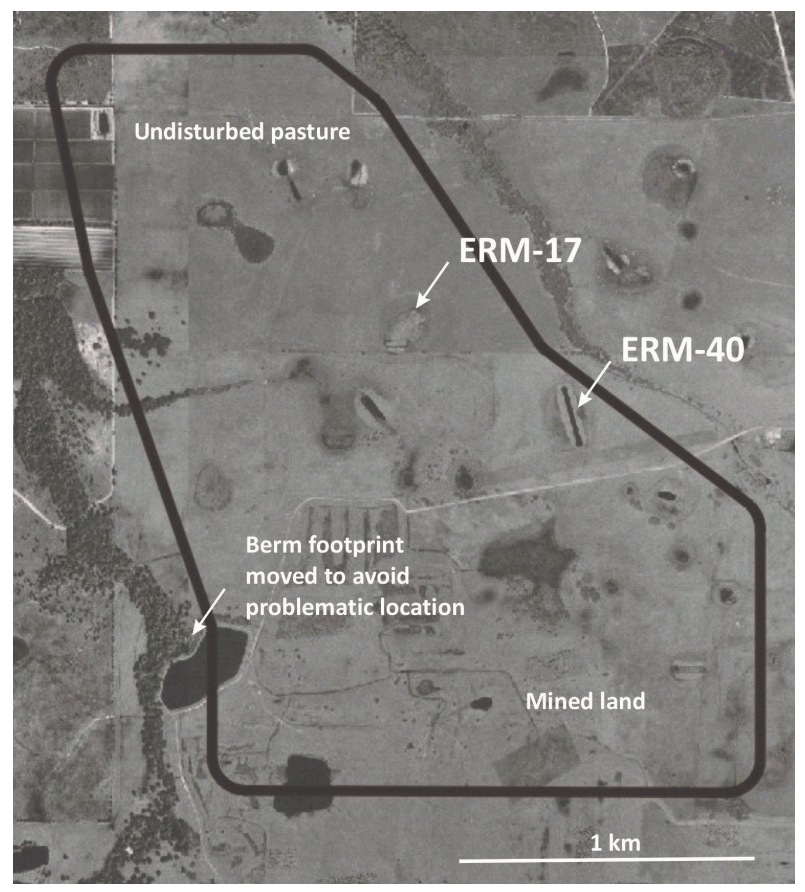

Figure 6. Aerial view of the C.W. "Bill" Young Reservoir site before construction. Dark line is the final location of the reservoir berm. Note the small stream channels and circular wetlands.

\section{Pedogenetic Depressions}

Altschuler et al. (1956, 1963) and Isphording (1984) have suggested that sediment volume reductions accompanying alteration of smectite to kaolinite within the Miocene sediments of Florida have caused shallow land-surface depressions (Table 1). It is likely that these depressions were the precursors of the depressions discussed above since they would have developed during the late Miocene/early Pliocene pedogenetic event.

\section{Karst or Pseudokarst?}

The discussion above has cataloged seven different forms of shallow depressions that occur on the land surface in the Florida Coastal Plain. The discussion has purposefully omitted cover-collapse sinkholes, which are often relatively deeper and more easily identified than the shallow depressions discussed herein.

It is apparent that the many land-surface depressions in Florida have diverse origins. One cannot simply conclude that natural depressions represent karst conditions. Table 2 indicates which types of depressions are karst related and which are pseudokarst. Only detailed analysis of the sediments within and below the depression will reveal whether the depression has a karst origin or is pseudokarst.

\section{Recommendations and Conclusions}

Seven different origins of shallow depressions have been identified in Florida. The abundance of these shallow depressions in many areas of the modern Coastal Plain may be dramatic (Figure 1). Determining the origins of these depressions and the risk(s) they pose is often confusing to lay persons and professionals alike.

Based on the authors' experiences, it is inappropriate to simply observe the field appearance of the depressions

Table 2. Types of depressions representing karstic or pseudokarstic processes.

\begin{tabular}{|l|l|}
\hline Depression Type & Karst or Pseudokarst? \\
\hline Cover-subsidence sinkhole & Karst \\
\hline Suffosion sinkhole & Karst \\
\hline Cover settlement over shell & Both exist \\
\hline Carolina bay-like depression & Pseudokarst* \\
\hline Aeolian deflation area & Pseudokarst \\
\hline Paleosol-related & Pseudokarst* \\
\hline Pedogenetic & Pseudokarst \\
\hline * May be associated with karst features such as sinkholes. \\
\hline
\end{tabular}


and conclude that they represent sinkholes or other karst features. It is strongly suggested that:

1. Only subsurface testing can determine their origin. Visually, the depressions appear similar and depressions with different origins are often mixed in an area.

2. Detailed analysis of the sediment stratigraphy, fabric, and texture is usually required to identify the origins of the depressions.

3. Petrographic, microscopic, and/or mineralogical analyses are often required to determine if shell and limestone has been subjected to dissolution or clays have been altered. Only a geochemical analysis of the pore water can determine if the dissolution is on-going.

\section{References}

Altschuler ZS, Jaffe EB, Cuttitta F. 1956. The aluminum phosphate zone of the Bone Valley Formation, Florida, and its uranium deposits. US Geological Survey Professional Paper 300: 495504.

Altschuler ZS, Jaffe EB, Dwornik E. 1951. The stratigraphy of the upper part of the Bone Valley Formation and its relation to the leached zone. US Geological Survey Trace Elements Memorandum Report 237.

Altschuler ZS, Dwornik EJ, Kramer H. 1963. Transformation of montmorillonite to kaolinite during weathering. Science 141 (3576): 148-152.

Beck BF, Sinclair WC. 1986. Sinkholes in Florida: An introduction. Orlando, Florida Sinkhole Research Institute Report 85-86-4.

Brooks MJ, Taylor BE, Stone PA, Gardner LR. 2001. Pleistocene encroachment on the Wateree River sand sheet into Big Bay on the middle Coastal Plain of South Carolina. Southeastern Geology 40 (4): 241-257.

Cathcart JB. 1963. Economic geology of the Keysville Quadrangle, Florida. US Geological Survey Bulletin 1128.

Cooke CW. 1954. Carolina bays and the shapes of eddies. US Geological Survey Professional Paper 254-I: 195-206.

Dobecki TL, Upchurch SB. 2010. A multi-level approach to site characterization - C.W. Bill Young Regional Reservoir, Hillsborough County, Florida. Proceedings of the Environmental and Engineering Geophysical Society, Application of Geophysics to Engineering and Environmental Problems (SAGEEP).
Eyton JR, Parkhurst JI. 1975. A re-evaluation of the extraterrestrial origin of the Carolina bays. University of Illinois at Urbana-Champaign, Occasional Publications of the Department of Geography Paper Number 9.

Field MS. 2002. A Lexicon of Cave and Karst Terminology with Special Reference to Environmental Karst Hydrology. US Environmental Protection Agency, EPA/600/R-02/003.

Grant JA, Brooks MJ, Taylor BE. 1998. New constraints on the evolution of Carolina bays from ground-penetrating radar. Geomorphology 22: 325-345.

Halladay WR. 2007. Pseudokarst in the 21st century. Journal of Cave and Karst Studies 69 (1): 103-113.

Isphording WC. 1984. Sand craters in Gulf Coastal Plain clastic sediments: An extension of the Carolina Bays phenomenon? Geological Society of America Abstracts with Programs 16 (3): 148.

Ivester AH, Brooks MJ, Taylor BE. 2007. Sedimentology and ages of Carolina bay sand rims. Geological Society of America Abstracts with Programs 39 (2): 5.

Legrand HE. 1953. Streamlining of the Carolina bays. Journal of Geology 61 (3): 263-274.

May JH, Warne AG. 2004. Hydrogeologic and geochemical factors required for the development of Carolina bays along the Atlantic and Gulf of Mexico Coastal Plain, USA. Environmental \& Engineering Geoscience 5 (3): 261-270.

Prouty WF. 1935. "Carolina bays" and elliptical lake basins. Journal of Geology 43 (2): 200-207.

Prouty WF. 1952. Carolina bays and their origin. Geological Society of America Bulletin 63 (2): 167-224.

Schalles JF, Sharitz RR, Gibbons JW, Leversee GJ, Knox JN. 1989. Carolina bays of the Savannah River Plant, Aiken, South Carolina. Aiken (SC) Savannah River Plant, National Environmental Research Park.

Schmidt W, Scott TM. 1984. Florida karst: its relationship to geologic structure and stratigraphy. In: Beck BF, editor. Sinkholes: Their Geology, Engineering and Environmental Impact. Proceedings of the First Multidisciplinary Conference on Sinkholes, Orlando, Florida, p. 11-16.

Upchurch SB, Dobecki TL, Daigle DM. 1999. Geological, hydrogeological, and geophysical investigation. In: Law Engineering Services and others, Geotechnical Site Characterization Report - Tampa Bay Regional Reservoir, Volume I, Section 3. 
Van Kauwenbergh SJ, Cathcart JB, McClellan GH. 1990. Mineralogy and alteration of the phosphate deposits of Florida. US Geological Survey Bulletin 1914.

Wells BW, Boyce SG. 1953. Carolina bays: Additional data on their origin, and history. Journal of the Mitchell Society 69 (2): 119-141.

White W. 1988. Geomorphology and hydrology of karst terrains. New York (NY): Oxford University Press.

White WA. 1970. The geomorphology of the Florida peninsula. Florida Geological Survey Bulletin 51.

Willoughby RH. 2007. Carolina bays in Jordan Quadrangle, Clarendon County, central South Carolina are relict survivors from development of sinkholes due to karstic solution. Geological Society of America Abstracts with Programs 39 (2): 5 . 
